\title{
Religious Leadership and Leadership Functions in the New Religions of Russia
}

\author{
Zoya E. Chernnyshkova and Alexey V. Osintsev* \\ Ural Federal University \\ named after the First President of Russia B.N. Yeltsin \\ 51 Lenina, Ekaterinburg, 620083, Russia
}

Received 06.11.2018, received in revised form 29.04.2019, accepted 08.05.2019

The article deals with the issues of religious leadership. The subject is the leadership of the new religions of Russia. The aim of the work is to identify the characteristic features of religious leadership in the present time. The methodological basis is a combination of methods of sociology of religion and interdisciplinary studies of leadership. As a result, we have identified the features of new types of leadership: leadership-moderation, decentralized leadership and informal leadership. For Russian new religions, the predominance of the author's character is quite typical. However, the creations and strategies of religious leaders are significantly influenced by multiple identity, virtualization and other phenomena.

Keywords: new religions, Russia, leadership, leadership strategies.

Research area: philosophy.

Citation: Chernnyshkova, Z.E., Osintsev, A.V. (2019). Religious leadership and leadership functions in the new religions of Russia. J. Sib. Fed. Univ. Humanit. soc. sci., 12(5), 764-770. DOI: $10.17516 / 1997-1370-0421$.

Religious leadership has been in the focus of scientific attention since the beginning of the $20^{\text {th }}$ century. M. Weber made a special contribution to the development of the problem by describing and categorizing leadership (Weber, 1920). There are many papers written on religious leadership, most of which belong to Western researchers. At the same time, the topic of leadership in the humanities was set by philosophers as the topic of creator and follower, master and subordinate, superman, active minority and passive majority (T. Carlyle, A. Bregson, F. Nietzsche, A. Toynbee, etc.). There is not so much domestic research on the topic of religious leadership carried out in the present time in comparison with the Western one. The reason for that is later appeal to the topic

(C) Siberian Federal University. All rights reserved

* Corresponding author E-mail address: alexosv@yandex.ru ORCID: 0000-0002-4543-115X (Osintsev)

This work is licensed under a Creative Commons Attribution-NonCommercial 4.0 International License (CC BY-NC 4.0). 
of new religions and new spirituality, leadership in new religions (Ageenkova E.K., Voropay S. Yu., Granovskaya R.M., Martinovich V.A., Trunov D.G., Titarenko V.V.). The problem of religious leadership in religious studies is mainly viewed through the prisms of the psychology and sociology of religion. Dominant points of view on the problem of religious leadership are related to the concepts of leadership by M. Weber.

Following the general concept of M. Weber's classification of religious leadership, we believe that it is applicable for the description of the empirical reality of the existing religious leaders of Russia's new religions. However, Weber's classification may be supplemented. We also believe that modern research in the field of management, team management and social psychology can be used to solve the problem of classifying religious leadership. The interdisciplinary perspective will make it possible to look at religious leadership as at the problem of interconnection between a flock and a leader, at leadership within a religious organization as a complex phenomenon characterized by the presence of several leadership centres, a shift of focus from leader to followers.

We believe that the models of leadership proposed by M. Weber, are preserved in modern conditions. However, in the $21^{\text {st }}$ century, the role of followers, or "following the leader," is increasing. This is not just a group of closest associates that influences the leader in decision-making, but also a wide circle of followers who, in the conditions of the information environment and freedom of communication, impose the theme of the day on religious leaders and influence the form of leadership and its manifestation. Moreover, in relation to the problem of leadership in such a phenomenon as alternative spirituality (expressive spirituality, new spirituality) these requirements of modernity are manifested to the maximum.

The institutionalization of religious activity is inextricably linked with the consolidation of the status of a religious leader, as a professional transmitter of rituals and an interpreter of religious standards. The special status of the head of a religious ritual first appeared in ancient times and is associated with the separation of a religious specialist, a shaman, a head of the ritual, and later a whole class of priesthood into a separate stratum of society. Since ancient times, these ritual specialists have been performing the function of mediation between the actually existing gods and people, and they manage the religious cult. Therefore, three main functions of a religious leader, which appeared in antiquity, are still preserved: a) the function of an intermediary between the earthly world and the other world; b) organizational function, i. e. group unification, effective building of various processes occurring in a group, organization, achievement of a declared goal; c) function of a moderator, i. e. determining the primary 
tasks and goals of the group, cutting off minor problems, determining the rules of interaction in the group, determining the rules of interpretation of religious ideas and the range of interpreters. Depending on the absolutisation of the leader's basis, various implementation strategies and an emphasis on a particular function arise.

The content and model of religious doctrine, as well as specific historical conditions influence the form of religious leadership. Therefore, the functions of religious leadership can be concentrated in one hands, and can be distributed between actors within a religious organization. In most cases, the longer an organization exists, changing its institutional forms (for example, becoming a church), the sooner a formal leader arises who heads the church and institutions, which receive some of the organization, mediation and moderation functions. In this case, there may be interesting demonstrations of the nature of leadership. On the one hand, religious leadership is always associated with the demonstration of a special status, position of a leader in a community, as a rule, a leader recognized by all and given the authority. On the other hand, in a religious organization there may be people involved and not involved in religious bureaucracy, but united by a common religious tradition, for example, such leaders who lead the clergy and form public opinion. The combination of formal and informal leadership in religious organizations is a specific norm that contributes to the sustainable development of a large structure. Since it is this combination that allows discussions to proceed peacefully, stimulates a dialogue, takes into account the variety of elements that make up a single structure.

Considering religious leadership in the new religions of Russia, one can speak of three types of leaders and their functions: creator, moderator and reformer. The creator of religion exercises their power in the community on the basis of the obtained revelation, secret mystical knowledge, power over supernatural forces, and a special connection with the Absolute. This type of leadership was classified by M. Weber as "charismatic". The criterion of the truth of the leadership nature for followers is their inner, irrational feelings, belief in the particular nature of the leader. We find all these features in the statements of their followers: N. Gornostayeva (Church of the Last Testament): "I was told that Vissarion is Christ, and I trusted this information with confidence, accepted him as the Messiah at once. This person always, from the very beginning, was Christ for me, I sincerely believed that this person is the Savior ... I accepted all the information that concerned the life of the community, the laws given by the Teacher, without any criticism, I trusted it easily" (Gornostayeva, 2009: 11). Thus, the charismatic type of leadership in new religious movements revives the idea 
of the "living God" in the sphere of religious consciousness. At the same time, if in the Christian tradition it is associated with obtaining spiritual grace, its expression in new religious movements is rather anthropocentric and emphasizes questions of the meaning of life, love, family and friendship. The main issues are shifted from the area of alleged relationship with a deity to interpersonal relationships.

The leading moderators include Evdokiya Marchenko (Evdokiya the Radiant), the founder of the Radasteya movement and the Institute of Rhythmology. Her teaching and method are a combination of quasi-scientific knowledge and the spiritual search of Evdokiya Marchenko, fragments of Eastern religions. If, in the case of Vissarion, first of all, attention is focused on the special nature of the charismatic leader and the legitimation of leadership through the function of an intermediary between the earthly and the heavenly, then in E. Marchenko's movement the moderation function comes to the fore. It is Evdokiya Marchenko who determines the tactics and strategy of the community (control of the poles of the world, the search for the rhythm), determines the order of speaking in the community and limits interpretations. The superiority of E. Marchenko is based on her unique abilities. However, her high level of knowledge within the framework of the doctrine itself is available to everyone with a certain diligence. In this regard, it is not by chance that religious scholars find similarities between rhythmology and Scientology. The best moderation can be carried out only by the founder, as the owner and developer of the method. Moderation occurs both directly and indirectly. The very language of rhythmology, the alphabet (omegavit, khladovit and radovit) and the procedure for actions at large annual meetings is under her control.

Another moderator is Vladimir Megre, the founder of the cult of Anastasia. As in the case with Radasteya, any person who enters the path of Anastasia (a fictional character in the books of V. Megre, a Siberian hermit) can achieve perfection. The Russian researcher of new religious movements I. Ia. Kanterov points out the absence of a rigid management structure as a distinguishing feature of the Anastasian movement (Kanterov, 2008). According to A.N. Raevskii's typology of New Age (Raevskii, 2012), the movement of Anastasians can be referred to the type of "auditorium cult" with an amorphous organizational structure. The Anastasians do not have a teacher, a leader. V. Megre himself avoids the role of a leader in every way: he refuses to create or manage any organizations. However, he still performs some moderation in the community. This occurs through the presentation of ideas in the ongoing books about Anastasia and around the topics related to her. Thus, the moderation in the cult of 
Anastasia is soft, contributing to the growth of discrepancies, however, holding the environmental pathos of the cult of Anastasia.

Among the striking examples of the modern-time leader-reformer is Veniamin Yakovlevich Bereslavsky (Archbishop Ioann), the founder of the "Orthodox Church of Our Sovereign Lady" or the "Center of the Mother of God" (Religiia i obshchestvo, 2002). Researchers attribute this movement to alternative Orthodoxy, which includes groups and communities that recognize Holy Scripture and Holy Tradition, the NiceneConstantinopolitan Creed and seven sacraments, but are not under the jurisdiction of any of the local Orthodox churches. These groups do not have canonical and eucharistic communion with Orthodox churches. In 1984, V. Bereslavsky announced a new revelation he received from the Mother of God. The new revelation is called the White Gospel, or the Third Testament. The purpose of the new revelation is the renewal of the Orthodox faith, the transformation of Orthodoxy into a more vibrant and emotional religion. From the point of view of V. Breslavsky, the Orthodox canon is not something eternal and unchanging, but developing. Church can make changes, the statements of the teachings. New views on the Orthodox cult resulted in its reformation and special emphasis was made on the organizational function of the leader, as a result of understanding him as a renewer of religion.

Conclusion. Despite the difference in the types of leadership in modern Russian religious genesis, the majority of modern religious projects are clearly personal and authorial in nature, which confirms Weber's viewpoint that charisma plays a decisive role in the genesis of religious communities. For objective reasons, the type of leadership is associated with the development of a religious community, the formation of a religious organization, and the process of its bureaucratization. However, such phenomena of modern Russian society as multiple identity, virtualization, immersion in a social and communicative environment, the market of religions leave their imprint on religious leadership. The need to respond to the demands of modernity leads to the fact that the type of leadership turns out to be more dynamic than a hundred years ago. In this regard, a leader is required not only to have a constructive imagination and will ("a person's ability to achieve a consciously set goal, while overcoming external and internal obstacles") but also considerable flexibility and change in leadership strategies (Bazarov, Shevchenko, 2014).

In modern times, there is a shift of focus from the leader to the "followers". These people influence leadership strategies more than before. This is not only the influence of the inner circle, but also of the distant environment, by which one can 
understand the whole community of believers. This is largely due to the existence of information, digital technologies, when the teacher is simultaneously and constantly in the field of view of a large number of followers. This leads to the mediation of religious leadership. Leaders-moderators, heads of the cults, such as the cult of Anastasia due to the specifics of leadership powers or the structure of the organization are also forced to especially carefully listen to the opinion of their followers, due to the lack of a rigid organizational core.

\section{References}

Bazarov, T. Yu. \& Shevchenko, Yu.S. (2014). Organizatsionnyi lider postkrizisnogo perioda [Organizational leader of the post-crisis period]. In Organizatsionnaya psikhologiia [Organizational psychology], 3, 69-86, 79.

Gornostayeva, N. (2009). Ismenit' sebia... [Change yourself...]. In Gazeta Tserkvi Poslednego Zaveta "Zemlya Obetovannaia" [Newspaper of the Church of the Last Testament "The Promised Land”], 34.

Kanterov, I. Ia. (2008). Utopiia v dukhe "New Age". Neskol'ko slov o predvziatoi otsenke novikh religioznykh iavlenii [Utopia in the spirit of "New Age". A few words about the biased assessment of new religious movements]. In NG-religii [NG religions].

Raevskii, A.N. (2012). Dvizhenie New Age kak kvazireligioznaia subkultura sovremennogo obshchestva: religiovedchesrii analiz [New Age movement as a quasireligious subculture of modern society: religious analysis]. Author's abstract for Candidate's Degree. Rostov-on-Don.

Religiia i obshchestvo. Ocherki religioznoi zhizni sovremennoi Rossii [Religion and society. Essays on religious life in modern Russia] (2002). Moscow — Saint Petersburg.

Weber, M. (1920). Die Wirtschaftsethik der Weltreligionen. In Weber M. Gesammelt Aufsätze zur Religionssoziologie. Tübingen, Bd. I. P. 237-275. 


\title{
Религиозное лидерство и лидерские функции \\ в новых религиях России
}

\author{
3.Е. Чернышкова, А.В. Осинцев \\ Уральский федеральный университет \\ им. первого Президента России Б. Н. Ельцина \\ Россия, 620083, Екатеринбург, пр. Ленина, 51
}

Статья посвящена вопросам религиозного лидерства. Предметом выступает лидерство в новых религиях России. Цель работы - выявление характерных черт религиозного лидерства в условиях современности. Методологическое основание работы заключается в дополнении методов социологии религии междисциплинарными исследованиями лидерства. Были получены следующие результаты: помимо признаков классических типов религиозного лидера, были выявлены черты новых типов лидерства: лидерство-модерачия, децентрализованное лидерство, неформальное лидерство. Российским новым религиям свойственно доминирование авторского характера. Однако на творения религиозных лидеров и на их стратегии оказывают существенное влияние такие явления, как множественная идентичность, виртуализация и др.

Ключевые слова: новые религии, Россия, лидерство, стратегии лидерства.

Научная специальность: 09.00.00 - философские науки. 